DOI: $\underline{10.20472 / E S .2018 .7 .2 .003}$

\title{
THE ETHICS OF TAX EVASION: A SURVEY OF LAW AND ECONOMICS STUDENTS IN THE REPUBLIC OF MACEDONIA
}

\section{ROBERT MCGEE, JOVAN SHOPOVSKI}

\begin{abstract}
:
This paper examines the ethical perception of tax evasion in the Republic of Macedonia. A survey consisting of 18 statements was distributed to 120 students; 107 responses were received. The results show that, in general, Macedonian students are intolerant towards tax evasion, perceiving it as an unethical behavior. However, only $45.3 \%$ of the students did not justify tax evasion in any of the 18 cases. Furthermore, male students were more tolerant towards tax evasion than their female colleagues. Law students were more supportive of tax evasion than their colleagues from the faculty of economics.
\end{abstract}

\section{Keywords:}

Tax evasion, Taxes, Ethics, Perception, Tax morale

JEL Classification: $\mathrm{H} 24, \mathrm{H} 26, \mathrm{H} 27$

\section{Authors:}

ROBERT MCGEE, Fayetteville State University, United States, Email: bob414@hotmail.com JOVAN SHOPOVSKI, European Scientific Institute, ESI, Macedoina, Email: jovanpraven@yahoo.com

\section{Citation:}

ROBERT MCGEE, JOVAN SHOPOVSKI (2018). The Ethics of Tax Evasion: A Survey of Law and Economics Students in the Republic of Macedonia. International Journal of Economic Sciences, Vol. VII(2), pp. 57-69., 10.20472/ES.2018.7.2.003 


\section{Introduction}

Taxes are the main instrument for financing state activities in providing public goods and services. Tax evasion reduces the amount of revenue government receives, and thus, according to Stern (1993), has a negative effect on economic growth and the fiscal policy of a country. The view that government expenditures have a positive effect on economic growth has been challenged by Rothbard (1963), among others (Batemarco, 1987; Vedder \& Gallaway, 1991), but a discussion of this point would take us too far afield of the present study, so we will leave discussion of this view for another time.

Tax evasion has been labeled as a global disease, which impose numerous economic effects to all societies (Johnson et al., 2000). Therefore, it is an issue which deserves great attention, since determining the level of tax evasion and having a better understanding of its reasons will help in the process of finding mechanisms to prevent it or decrease its intensity.

Alm and Torgler (2012) confirmed the importance of voluntarily paying taxes by highlighting the fact that, in practice, only $1 \%$ of taxpayers succumbed to tax controls. This means that even though tax controls and penalties are an important part of the tax collection process, existence of a shadow economy and tax evasion in every society refers to the importance of tax morale.

Tax evasion is a serious problem for developing countries. This is mostly because these countries in their transition process, from state controlled to market oriented economies, are facing huge institutional, behavior, and cultural changes. Undoubtedly, these changes have a negative effect on the collected revenue and it limits the capacity of the State and its institutions. These factors increase the level of tax evasion (Abdixhiku, Besnik, Pugh \& Hashi, 2017).

The paper will provide data and conclusions based on its own survey, i.e., primary sources regarding the level of tax evasion in the Republic of Macedonia. It will examine the perception of Macedonian law and economics students towards tax evasion and how often they justify it. It aims to fill the existent gap in the literature on this issue and it can be used as a source for further actions towards decreasing the level of tax evasion and strengthening tax morale.

\section{Literature Review}

Tax evasion is a topic that attracts the attention of academic researchers. Adams $(1983,1992)$ analyzed this phenomenon historically, covering a period of 2000 years. Factors that trigger tax evasion are usually the main focus of these types of research. It seems that the common reasons for tax evasion are the fact that people can evade taxes, or they do not believe that the government is entitled to a portion of their income (McGee, 2014). Crowe (1944), after surveying more than 500 years of religious and philosophical literature, identified unfairness of the tax system, government corruption, wasting the tax funds, not receiving any benefit or the inability to pay taxes, to be some of the most common reasons why people justify tax evasion. 
From a religious point of view, even though tax evasion has not always been justified, it can be said that there is no absolute opposition to tax evasion, or there are always situations where one can justify it up to a certain extent. The Mormon religion is the religion most strongly opposed to tax evasion, since its literature does not provide a single case where it can be justified (Smith \& Kimble, 1998). However, McGee and Smith (2012) stated that the actual members of the Mormon community are flexible regarding this issue (McGee, 2014). The Baha'i religion is almost as unanimous and does not support tax evasion, except in one case. Their only exception is in cases where the government persecutes their members (DeMoville, 1998). Cohn (1998, 2012) and Tamari (1998) confirmed that, in general, Jews are strongly opposed to tax evasion. McGee and Cohn (2008) found that the strongest argument for Orthodox Jewish students to justify tax evasion is when they pay taxes and Hitler is the tax collector. However, even here, the moral justification to evade tax evasion was less than total.

The Jewish literature gives at least three reasons why Jews might have a moral obligation to pay taxes even if Hitler were the tax collector (Cohn, 1998, 2012; McGee \& Cohn, 2008). For one, there is the belief that the law is the law, meaning all laws must be obeyed, no matter how bad they might be. Gandhi, Martin Luther King, Thoreau and others would challenge this view. Indeed, Martin Luther King (1963) has asserted that there is a moral duty to disobey unjust laws. Saint Augustine (2010) has said that an unjust law is no law at all.

The second justification in the Jewish literature for paying taxes to Hitler is based on the belief that one must never do anything to disparage another Jew. In other words, one must never do anything to make another Jew look bad. This argument also falls apart upon analysis. The goodness or badness of an act is not determined by what others might think, and different members of the community might have different views on the act.

The third justification for Jews to pay taxes to Hitler is that tax evasion might cause one to go to prison, and since there is a moral duty to perform mitzvas (good works), doing so might not be possible if one is in prison. Of course, one might easily argue that it might actually be easier to find opportunities to perform good works in prison than on the outside, which is only one of several arguments that could be made to challenge this view.

Two different views can be found in the Muslim literature. Ahmad (1995) and Yusuf (1971) interpreted the Muslim literature to hold that there is no moral duty to pay a tax that is based on income, or a tax that causes prices to rise, which would include tariffs and sales/value added taxes. However, Jalili (2012) disagreed with this view and interpreted the Muslim literature to take the position that tax evasion is always unethical, but only in cases where the country is ruled by Sharia law. Evading taxes in such cases would be stealing from Allah. However, evading taxes in a state not ruled by Sharia law might not be viewed as unethical in some cases, although he did not elaborate on the specifics.

It is difficult to say what the Catholic, Protestant or Christian views on tax evasion might be, since the literature from these groups presents several different and conflicting views (Crowe, 1944; Gronbacher, 1998; McGee, 2012; Pennock, 1998; Schansberg, 1998). All that can be said is that the Christian literature, with the 
exception of the Mormon literature, provides some support for the view that tax evasion can be justified under certain circumstances.

Torgler $(2003,362)$ argued that tax morale in transition nations is rather low when compared to countries in Central and West Europe. Over 60 percent of those surveyed in the West European countries were of the opinion that tax cheating was never acceptable, while only 42.6 percent of those surveyed in the East European countries confirmed this statement. Clearly, tax morale is weaker in the former Communist nations. However, the key factors that shape tax morale in both Western and Eastern European countries are trust in government and trust in the country's legal system (Torgler, 2004, cited by Uslaner, 2008).

McGee (2012) supported this view based on the findings that in the former Soviet Republics and former communist countries in Central and Eastern Europe, people evade taxes due to the inadequate collection system and the fact that taxpayers believe that the government does not deserve part of their income.

The factors that influence the tax morale of the taxpayers in the Republic of Macedonia were analyzed by using data of the European Values Study (EVS) gathered in 2008. Ristovska, Mojsoska-Blazeski and Nikolov (2013) concluded that according to these data, $81 \%$ of the respondents in the Republic of Macedonia do not justify tax evasion in any case. This is certainly a great percentage and can refer to high tax morale among the taxpayers in the country. However, those secondary sources revealed a huge disparity among the respondents and their tax morale, especially when it comes to their ethnic background, religion, and the language they speak. Age, marital status, and level of education were also factors that had a significant influence on tax morale (Ristovska et al., 2013).

While $96 \%$ of the respondents from the South Eastern part of the country did not justify tax evasion, reporting high tax morale, only $57 \%$ of those who lived in the South West of Macedonia and $44 \%$ in the Western part were against tax evasion. Moreover, $90 \%$ of the Orthodox Christians did not justify tax evasion in any case while this was the case for only $45 \%$ of the Muslims in the country. $90 \%$ of those who speak the Macedonian language as their first language reported a high level of tax morale, compared to those who spoke another language as their native language rather than the Macedonian language. The number in this case was 33\%. Those who were strongly against tax evasion were those who reported a high level of national pride, and who believed in the government and the legal system (Ristovska et al., 2013).

\section{Methods and Results}

A survey was conducted using Robert W. McGee`s 18 statement questionnaire regarding the ethics of tax evasion. It is a semi-structured questionnaire with statements that show that tax evasion is ethical in different situations. Most of the 18 statements were based on the reasons given in the Crowe (1944) study for justifying tax evasion historically.

The respondents, however, were asked to choose the extent to which they agreed with every statement by grading each statement on a scale from 1 to 7 . At the very beginning of the questionnaire, a clarification on the terms "tax evasion" and "tax 
avoidance" was given in order to establish a clear difference between them. Thus, tax evasion can be defined as the illegal nonpayment of a tax, while tax avoidance occurs when someone finds a way to legally minimize or reduce taxes. Moreover, an adjustment in the translation was made in order to obtain the same terms and meaning in accordance with the Macedonian Criminal Codes, where these institutes are regulated.

In addition, the main part of the questionnaire consisted of the 18 statements with the request for grading each of them with the statement. This grading ranged from 1 (strongly disagree) to 7 (strongly agree). The anonymity of the survey was guaranteed through the absence of any request for the name of the respondents. However, after the statements, there is a part for collecting general data from the participant. Firstly, the students were asked to provide information whether they were undergraduate or postgraduate students and if they were students at the faculty of law or the faculty of economics. Furthermore, they were also asked about their age, religion, and ethnicity. At the end of the questionnaire, there was a place for additional comments, where the respondents were allowed to express their views on ethics and tax evasion or what determines when tax evasion is ethical or unethical, etc.

Responses from 107 students in the Republic of Macedonia were collected between October $1-4,2017.28 \%$ of the respondents were students at the faculty of economics and $72 \%$ at the faculty of law. $30 \%$ of them were male, while two-thirds were female students. All but two were under 25 years old.

The majority, $95 \%$, of the respondents were ethnically Macedonian, while $90 \%$ were orthodox.

The results of the survey are presented through tables. The average support of every statement will be shown. From these results, a conclusion regarding the support of tax evasion could be derived.

\section{Table 1. Ethics of tax evasion}

1 (strongly disagree) to 7 (strongly agree)

\begin{tabular}{|l|l|}
\hline & \\
\hline 1. Tax evasion is ethical if tax rates are too high. & 2.653846154 \\
\hline $\begin{array}{l}\text { 2. Tax evasion is ethical even if tax rates are not too high } \\
\text { because the government is not entitled to take as much as it is } \\
\text { taking from me. }\end{array}$ & 2.487179487 \\
\hline 3. Tax evasion is ethical if the tax system is unfair. & 3.551282051 \\
\hline $\begin{array}{l}\text { 4. Tax evasion is ethical if a large portion of the money collected } \\
\text { is wasted. }\end{array}$ & 2.730769231 \\
\hline
\end{tabular}




\begin{tabular}{|c|c|}
\hline $\begin{array}{l}\text { 5. Tax evasion is ethical even if most of the money collected is } \\
\text { spent wisely. }\end{array}$ & 2.397435897 \\
\hline $\begin{array}{l}\text { 6. Tax evasion is ethical if a large portion of the money collected } \\
\text { is spent on projects that I morally disapprove of. }\end{array}$ & 2.628205128 \\
\hline $\begin{array}{l}\text { 7. Tax evasion is ethical even if a large portion of the money } \\
\text { collected is spent on worthy projects. }\end{array}$ & 2.423076924 \\
\hline $\begin{array}{l}\text { 8. Tax evasion is ethical if a large portion of the money collected } \\
\text { is spent on projects that do not benefit me. }\end{array}$ & 2.217948718 \\
\hline $\begin{array}{l}\text { 9. Tax evasion is ethical even if a large portion of the money } \\
\text { collected is spent on projects that do benefit me. }\end{array}$ & 2.423076923 \\
\hline 10. Tax evasion is ethical if everyone is doing it. & 2.602564103 \\
\hline $\begin{array}{l}\text { 11. Tax evasion is ethical if a significant portion of the money } \\
\text { collected winds up in the pockets of corrupt politicians or their } \\
\text { families and friends. }\end{array}$ & 2.91025641 \\
\hline $\begin{array}{l}\text { 12. Tax evasion is ethical if the probability of getting caught is } \\
\text { low. }\end{array}$ & 2.064102564 \\
\hline $\begin{array}{l}\text { 13. Tax evasion is ethical if some of the proceeds go to support } \\
\text { a war that I consider to be unjust. }\end{array}$ & 2.333333333 \\
\hline 14. Tax evasion is ethical if I car & 3.038461538 \\
\hline $\begin{array}{l}\text { 15. Tax evasion is ethical even if it means that if I pay less, } \\
\text { others will have to pay more. }\end{array}$ & 2.076923077 \\
\hline $\begin{array}{l}\text { 16. Tax evasion would be ethical if I were a Jew living in Nazi } \\
\text { Germany. }\end{array}$ & 1.961538462 \\
\hline $\begin{array}{l}\text { 17. Tax evasion is ethical if the government discriminates } \\
\text { against me because of my religion, race or ethnic background. }\end{array}$ & 2.987179487 \\
\hline $\begin{array}{l}\text { 18. Tax evasion is ethical if the government imprisons people for } \\
\text { their political opinions. }\end{array}$ & 2.948051948 \\
\hline
\end{tabular}

Source: Survey conducted for this paper

The average result for every statement is presented in Table 1 . The higher the number, the more supportive the students are towards tax evasion and vice versa. However, it is clear that there was not great support for tax evasion among the Macedonian students. The greatest justification was for the statement that tax evasion is ethical if the tax system is unfair. It is a general statement where it is not explained with regard to what makes the tax system unfair. 
The second most supported statement was that tax evasion is ethical if the respondent cannot afford to pay. Next is the statement that evasion is ethical if the government discriminates against its citizens on a basis of race, religion or ethnic background. A nearly equal score was had for the statement as to when the government imprisons people for their political opinions.

Contrary to expectations, the least support was for the statement that tax evasion would have been ethical if the taxpayer were a Jew in a Nazi Germany. It happened that Macedonian students were not very supportive of tax evasion even in this hypothetical situation. Furthermore, Macedonian students do not perceive tax evasion as an ethical thing even when the probability of getting caught is low, which was one of the reasons found by Crowe (1944) in his examination of the religious literature. This might refer to the fact that potential penalties are not always a key reason for paying taxes.

Table 2 presents the statements according to the support they received, starting from the one with the highest level of support.

Table 2. The statements on how ethical tax evasion is, according to the support they have received, ranking from most to least support.

1 (strongly disagree) to 7 (strongly agree)

\begin{tabular}{|l|l|}
\hline & \\
\hline 1. Tax evasion is ethical if the tax system is unfair. & 3.551282051 \\
\hline 2. Tax evasion is ethical if I can't afford to pay. & 3.038461538 \\
\hline $\begin{array}{l}\text { 3. Tax evasion is ethical if the government discriminates against } \\
\text { me because of my religion, race or ethnic background. }\end{array}$ & 2.987179487 \\
\hline & \\
\hline $\begin{array}{l}\text { 4. Tax evasion is ethical if the government imprisons people for } \\
\text { their political opinions. }\end{array}$ & 2.948051948 \\
\hline $\begin{array}{l}\text { 5. Tax evasion is ethical if a significant portion of the money } \\
\text { collected winds up in the pockets of corrupt politicians or their } \\
\text { families and friends. }\end{array}$ & 2.91025641 \\
\hline $\begin{array}{l}\text { 6. Tax evasion is ethical if a large portion of the money collected } \\
\text { is wasted. }\end{array}$ & 2.730769231 \\
\hline 7. Tax evasion is ethical if tax rates are too high. & 2.653846154 \\
\hline $\begin{array}{l}\text { 8. Tax evasion is ethical if a large portion of the money collected } \\
\text { is spent on projects that I morally disapprove of. }\end{array}$ & 2.628205128 \\
\hline 9. Tax evasion is ethical if everyone is doing it. & 2.602564103 \\
\hline $\begin{array}{l}\text { 10. Tax evasion is ethical even if tax rates are not too high } \\
\text { because the government is not entitled to take as much as it is } \\
\text { taking from me. }\end{array}$ & 2.487179487 \\
\hline $\begin{array}{l}\text { 11. Tax evasion is ethical even if a large portion of the money } \\
\text { collected is spent on worthy projects. }\end{array}$ & 2.423076924 \\
\hline $\begin{array}{l}\text { 12. Tax evasion is ethical even if a large portion of the money } \\
\text { collected is spent on projects that do benefit me. }\end{array}$ & 2.423076923 \\
\hline $\begin{array}{l}\text { 13. Tax evasion is ethical even if most of the money collected is } \\
\text { spent wisely. }\end{array}$ & 2.397435897 \\
\hline
\end{tabular}




\begin{tabular}{|l|l|}
\hline $\begin{array}{l}\text { 14. Tax evasion is ethical if some of the proceeds go to support a } \\
\text { war that I consider to be unjust. }\end{array}$ & 2.333333333 \\
\hline $\begin{array}{l}\text { 15. Tax evasion is ethical if a large portion of the money collected } \\
\text { is spent on projects that do not benefit me. }\end{array}$ & 2.217948718 \\
\hline $\begin{array}{l}\text { 16. Tax evasion is ethical even if it means that if I pay less, others } \\
\text { will have to pay more. }\end{array}$ & 2.076923077 \\
\hline $\begin{array}{l}\text { 17. Tax evasion is ethical if the probability of getting caught is } \\
\text { low. }\end{array}$ & 2.064102564 \\
\hline $\begin{array}{l}\text { 18. Tax evasion would be ethical if I were a Jew living in Nazi } \\
\text { Germany. }\end{array}$ & 1.961538462 \\
\hline
\end{tabular}

Source: Survey conducted for this paper

Table 3. Justification of tax evasion among the Macedonian students

\begin{tabular}{|l|l|l|l|l|l|l|l|}
\hline & \multicolumn{1}{|c|}{1} & \multicolumn{1}{|c|}{2} & \multicolumn{1}{|c|}{3} & \multicolumn{1}{c|}{4} & \multicolumn{1}{c|}{5} & 7 \\
\hline 1. & $41.7 \%$ & $12.9 \%$ & $11.7 \%$ & $15.5 \%$ & $12.9 \%$ & $1.4 \%$ & $3.9 \%$ \\
\hline 2. & $42.9 \%$ & $12.9 \%$ & $20.8 \%$ & $9.09 \%$ & $9.09 \%$ & $2.59 \%$ & $2.59 \%$ \\
\hline 3. & $24.7 \%$ & $7.79 \%$ & $23.3 \%$ & $14.2 \%$ & $7.9 \%$ & $11.7 \%$ & $10.4 \%$ \\
\hline 4. & $38.9 \%$ & $16.9 \%$ & $9.09 \%$ & $16.9 \%$ & $5.19 \%$ & $5.19 \%$ & $5.19 \%$ \\
\hline 5. & $40.1 \%$ & $25.9 \%$ & $12.9 \%$ & $9.09 \%$ & $6.3 \%$ & $5.19 \%$ & $2.59 \%$ \\
\hline 6. & $37.6 \%$ & $14.2 \%$ & $19.4 \%$ & $16.8 \%$ & $2.59 \%$ & $6.4 \%$ & $2.59 \%$ \\
\hline 7. & $48 \%$ & $16.8 \%$ & $12.9 \%$ & $3.89 \%$ & $7.79 \%$ & $3.89 \%$ & $6.4 \%$ \\
\hline 8. & $53.2 \%$ & $11.6 \%$ & $16.8 \%$ & $6.4 \%$ & $2.59 \%$ & $5.19 \%$ & $3.89 \%$ \\
\hline 9. & $40.2 \%$ & $18.3 \%$ & $22 \%$ & $7.7 \%$ & $2.59 \%$ & $3.89 \%$ & $5.19 \%$ \\
\hline 10. & $46.7 \%$ & $16.8 \%$ & $9.09 \%$ & $7.79 \%$ & $3.89 \%$ & $1.29 \%$ & $14.2 \%$ \\
\hline 11. & $50.6 \%$ & $11.6 \%$ & $6.49 \%$ & $6.49 \%$ & $0 \%$ & $6.49 \%$ & $18.1 \%$ \\
\hline 12. & $59.7 \%$ & $15.5 \%$ & $10.3 \%$ & $5.19 \%$ & $3.89 \%$ & $0 \%$ & $5.19 \%$ \\
\hline 13. & $48 \%$ & $18.1 \%$ & $9.09 \%$ & $11.6 \%$ & $6.4 \%$ & $1.2 \%$ & $5.19 \%$ \\
\hline 14. & $36.3 \%$ & $16.8 \%$ & $11.6 \%$ & $9.09 \%$ & $6.49 \%$ & $7.79 \%$ & $11.6 \%$ \\
\hline 15. & $59.7 \%$ & $11.6 \%$ & $12.9 \%$ & $2.59 \%$ & $5.19 \%$ & $3.89 \%$ & $3.89 \%$ \\
\hline 16. & $64.9 \%$ & $14.2 \%$ & $3.89 \%$ & $7.79 \%$ & $2.59 \%$ & $1.29 \%$ & $5.19 \%$ \\
\hline 17. & $44.1 \%$ & $14.2 \%$ & $6.49 \%$ & $7.79 \%$ & $7.79 \%$ & $1.29 \%$ & $18.1 \%$ \\
\hline 18. & $38.9 \%$ & $19.4 \%$ & $9.09 \%$ & $5.19 \%$ & $5.19 \%$ & $6.49 \%$ & $15.5 \%$ \\
\hline
\end{tabular}

Source: Survey conducted for this paper

Additionally, the percentage obtained for every single statement in Table 3 will provide a thorough summary of the results. For example, for Statement 1, the percentage of respondents who believed that tax evasion would never be justified was $41.7 \%$, whereas $3.9 \%$ believed it could always be justified.

On average, $45.3 \%$ of the respondents were absolutely against tax evasion and did not justify tax evasion under any circumstances. However, the majority (54.7\%), which is a significant portion, was more or less tolerant to tax evasion, depending on the circumstances. 
According to the results presented in Table 4, male respondents evaluated the statements with higher scores compared to their female colleagues. This means that there is more justification of tax evasion among the male students. They considered tax evasion an ethical thing more often than their female colleagues. The difference is obvious. The results are presented in Table 4 below.

\section{Table 4. Ethics of tax evasion according to gender}

1 (strongly disagree) to 7 (strongly agree)

\begin{tabular}{|c|c|c|}
\hline & $\mathrm{M}$ & $\mathrm{F}$ \\
\hline 1. Tax evasion is ethical if the tax system is unfair. & 3.037037037 & 2.980392157 \\
\hline 2. Tax evasion is ethical if I can't afford to pay. & 3.296296296 & 2.823529412 \\
\hline $\begin{array}{l}\text { 3. Tax evasion is ethical if the government } \\
\text { discriminates against me because of my religion, } \\
\text { race or ethnic background. }\end{array}$ & 1.974968969 & 1.960784314 \\
\hline $\begin{array}{l}\text { 4. Tax evasion is ethical if the government } \\
\text { imprisons people for their political opinions. }\end{array}$ & 2.407407407 & 2.294117647 \\
\hline $\begin{array}{l}\text { 5. Tax evasion is ethical if a significant portion of } \\
\text { the money collected winds up in the pockets of } \\
\text { corrupt politicians or their families and friends. }\end{array}$ & 3.037037037 & 3.039215686 \\
\hline $\begin{array}{l}\text { 6. Tax evasion is ethical if a large portion of the } \\
\text { money collected is wasted. }\end{array}$ & 2.407407407 & 2.294117647 \\
\hline 7. Tax evasion is ethical if tax rates are too high. & 2.481481481 & 1.843137255 \\
\hline $\begin{array}{l}\text { 8. Tax evasion is ethical if a large portion of the } \\
\text { money collected is spent on projects that I morally } \\
\text { disapprove of. }\end{array}$ & 3.111111111 & 2.803921569 \\
\hline 9. Tax evasion is ethical if everyone is doing it. & 2.962962963 & 2.411764706 \\
\hline $\begin{array}{l}\text { 10. Tax evasion is ethical even if tax rates are not } \\
\text { too high because the government is not entitled to } \\
\text { take as much as it is taking from me. }\end{array}$ & 2.666666667 & 2.294117647 \\
\hline $\begin{array}{l}\text { 11. Tax evasion is ethical even if a large portion of } \\
\text { the money collected is spent on worthy projects. }\end{array}$ & 2.407407407 & 2.117647059 \\
\hline $\begin{array}{l}\text { 12. Tax evasion is ethical even if a large portion of } \\
\text { the money collected is spent on projects that do } \\
\text { benefit me. }\end{array}$ & 2.222222222 & 2.529411765 \\
\hline $\begin{array}{l}\text { 13. Tax evasion is ethical even if most of the } \\
\text { money collected is spent wisely. }\end{array}$ & 2.814814815 & 2.529411765 \\
\hline $\begin{array}{l}\text { 14. Tax evasion is ethical if some of the proceeds } \\
\text { go to support a war that I consider to be unjust. }\end{array}$ & 2.444444444 & 2.37254902 \\
\hline
\end{tabular}




\begin{tabular}{|l|l|l|}
$\begin{array}{l}\text { 15. Tax evasion is ethical if a large portion of the } \\
\text { money collected is spent on projects that do not } \\
\text { benefit me. }\end{array}$ & 3.074074074 & 2.549019608 \\
\hline $\begin{array}{l}\text { 16. Tax evasion is ethical even if it means that if I } \\
\text { pay less, others will have to pay more. }\end{array}$ & 3.481481481 & 3.588235294 \\
\hline $\begin{array}{l}\text { 17. Tax evasion is ethical if the probability of } \\
\text { getting caught is low. }\end{array}$ & & \\
\hline $\begin{array}{l}\text { 18. Tax evasion would be ethical if I were a Jew } \\
\text { living in Nazi Germany. }\end{array}$ & 2.407407407 & 2.529411765 \\
\hline
\end{tabular}

Source: Survey conducted for this paper

Another interesting and valuable comparison is the relative views of the law and economics students. $28 \%$ of the total respondents are students at the faculty of economics, while $72 \%$ are law students. Table 5 presents the results.

Table 5. Ethics of tax evasion according to the faculty of the respondents 1 (strongly disagree) to 7 (strongly agree)

\begin{tabular}{|c|c|c|}
\hline 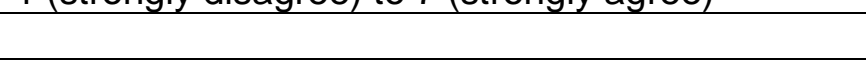 & Law & Economics \\
\hline $\begin{array}{l}\text { 1. Tax evasion is ethical if the tax system is } \\
\text { unfair. }\end{array}$ & 3.529411765 & 2.037037037 \\
\hline 2. Tax evasion is ethical if I can't afford to pay. & 3.450980392 & 2.111111111 \\
\hline $\begin{array}{l}\text { 3. Tax evasion is ethical if the government } \\
\text { discriminates against me because of my religion, } \\
\text { race or ethnic background. }\end{array}$ & 2.078431373 & 1.740740741 \\
\hline $\begin{array}{l}\text { 4. Tax evasion is ethical if the government } \\
\text { imprisons people for their political opinions. }\end{array}$ & 2.274509804 & 1.703703704 \\
\hline $\begin{array}{l}\text { 5. Tax evasion is ethical if a significant portion of } \\
\text { the money collected winds up in the pockets of } \\
\text { corrupt politicians or their families and friends. }\end{array}$ & 3.098039216 & 2.925925926 \\
\hline $\begin{array}{l}\text { 6. Tax evasion is ethical if a large portion of the } \\
\text { money collected is wasted. }\end{array}$ & 2.607843137 & 1.814814815 \\
\hline 7. Tax evasion is ethical if tax rates are too high. & 2.235294118 & 1.740740741 \\
\hline $\begin{array}{l}\text { 8. Tax evasion is ethical if a large portion of the } \\
\text { money collected is spent on projects that I } \\
\text { morally disapprove of. }\end{array}$ & 3.215686275 & 2.333333333 \\
\hline 9. Tax evasion is ethical if everyone is doing it. & 2.68627451 & 2.444444444 \\
\hline $\begin{array}{l}\text { 10. Tax evasion is ethical even if tax rates are } \\
\text { not too high because the government is not } \\
\text { entitled to take as much as it is taking from me. }\end{array}$ & 2.450980392 & 2.37037037 \\
\hline $\begin{array}{l}\text { 11. Tax evasion is ethical even if a large portion } \\
\text { of the money collected is spent on worthy } \\
\text { projects. }\end{array}$ & 2.235294118 & 2.185185185 \\
\hline $\begin{array}{l}\text { 12. Tax evasion is ethical even if a large portion } \\
\text { of the money collected is spent on projects that } \\
\text { do benefit me. }\end{array}$ & 2.490196078 & 2.29629 \\
\hline
\end{tabular}




\begin{tabular}{|c|c|c|}
\hline $\begin{array}{l}\text { 13. Tax evasion is ethical even if most of the } \\
\text { money collected is spent wisely. }\end{array}$ & 2.68627451 & 2.518518519 \\
\hline $\begin{array}{l}\text { 14. Tax evasion is ethical if some of the } \\
\text { proceeds go to support a war that I consider to } \\
\text { be unjust. }\end{array}$ & 2.352941176 & 2.481481481 \\
\hline $\begin{array}{l}\text { 15. Tax evasion is ethical if a large portion of the } \\
\text { money collected is spent on projects that do not } \\
\text { benefit me. }\end{array}$ & 3.117647059 & 2.037037037 \\
\hline $\begin{array}{l}\text { 16. Tax evasion is ethical even if it means that if I } \\
\text { pay less, others will have to pay more. }\end{array}$ & 3.862745098 & 2.962962963 \\
\hline $\begin{array}{l}\text { 17. Tax evasion is ethical if the probability of } \\
\text { getting caught is low. }\end{array}$ & 2.568627451 & 2.333333333 \\
\hline $\begin{array}{l}\text { 18. Tax evasion would be ethical if I were a Jew } \\
\text { living in Nazi Germany. }\end{array}$ & 2.745098039 & 2.481481481 \\
\hline
\end{tabular}

Source: Survey conducted for this paper.

As shown in Table 5, law students gave higher scores for the statements, which means a greater tolerance towards tax evasion. Not only is there a difference, in all the cases except for one, but these differences are also significant.

\section{Limitations and Discussion}

One of the limitations of the study is the inability to make a comparison on the basis of ethnic background. This is due to the fact that the great majority of the students are from the same ethnic background. It also applies to the language of the respondents. The vast majority of the respondents speak Macedonian as their primary language.

Another limitation is the religion of the participants. Most of them were Orthodox Christians, and therefore any meaningful kind of comparison based on religion would not be possible. However, this could be the basis for further research. Some previous studies argued that there was a significant difference on tax morale among the taxpayers of different ethnic origin and religion in various other countries.

Nevertheless, this article is the first one of its type where data based on a specially designed questionnaire have been collected. It also targeted students in the Republic of Macedonia as a progressive group with insights on the topic. Therefore, the results can be useful in the process of policy creation for increasing the tax morale and coping with tax evasion.

\section{Conclusion}

In general, Macedonian students are not tolerant towards tax evasion. $45.3 \%$ of them chose the lowest possible grade for the 18 statements, choosing not to justify tax evasion for any reason. However, the majority of the responses (54.7\%) justify tax evasion to a certain extent. This means that a significant part of the responses are supportive of tax evasion to a certain extent, depending on the situation.

Moreover, male students were far more tolerant of tax evasion compared to their female colleagues. Law students also gave higher grades to the statements, which 
means a higher justification for tax evasion than their colleagues at the faculty of economics.

This study has certain policy implications. For example, if the government wants to reduce the acceptability of tax evasion, it could adopt policies that reduce the validity of excuses for evading taxes. It could offer the people a just government that is not corrupt and that has a tax system perceived as fair. It could keep rates low enough so that people are able to pay. It could provide a high level of services in exchange for the tax payments so that taxpayers could feel they were receiving some value in exchange for their tax payments.

\section{References}

ABDIXHIKU, L., BESNIK, K., PUGH, G., and HASHI, I. (2017) Firm-level determinants of tax evasion in transition economies. Economic Systems. 2017, Vol. 41, No. 3, s. 354-366. https://doi.org/10.1016/j.ecosys.2016.12.004

ADAMS, C. (1982). Fight, Flight and Fraud: The Story of Taxation. Curacao: Euro-Dutch Publishers, 1982.

ADAMS, C. (1993). For Good or Evil: The Impact of Taxes on the Course of Civilization. London: Madison Books, 1993.

AHMAD, M. (1995). Business Ethics in Islam. Islamabad, Pakistan: The International Institute of Islamic Thought \& The International Institute of Islamic Economics,1995.

ALM, J. and MCCLELLAN, N. (2012). Rethinking the Research Paradigms for Analyzing Tax Compliance Behavior. Tulane University Department of Economics, Working Papers 1210.

AUGUSTINE, SAINT. (2010). On Free Choice of the Will, Book 1, para. 5. Reprinted in On the Free Choice of the Will, On Grace and Free Choice, and Other Writings (Peter King, ed.), New York: Cambridge University Press, 2010.

BATEMARCO, R. (1987). GNP, PPR, and the Standard of Living. Review of Austrian Economics Vol. 1, s. 181-186. https://doi.org/10.1007/BF01539339

COHN, G. (1998). The Jewish View on Paying Taxes. Journal of Accounting, Ethics \&. Public Policy, 1998, Vol. 1, No. 2, s. 109-120. https://doi.org/10.1023/A:1009738415952

COHN, G. (2012). The Traditional Jewish View of Paying Taxes, in R. W. McGee (ed.), The Ethics of Tax Evasion: Perspectives in Theory and Practice, 2012, New York: Springer, s,. 149-158. https://doi.org/10.1007/978-1-4614-1287-8_9

CROWE, M. T. (1944). The Moral Obligation of Paying Just Taxes, Washington, DC: The Catholic University of America, 1944.

DEMOVILLE, W. (1998). The Ethics of Tax Evasion: A Baha'i Perspective. Journal of Accounting, Ethics \&. Public Policy, 1998. Vol. 1, No. 3, s. 356-368.

GRONBACHER, G.M.A. (1998). Taxation: Catholic Social Thought and Classical Liberalism. Journal of Accounting, Ethics \& Public Policy, 1998. Vol. 1, No. 1, s. 91-100.

JALILI, A. R. (2012). The Ethics of Tax Evasion: An Islamic Perspective, in R. W. McGee (ed.), The Ethics of Tax Evasion: Perspectives in Theory and Practice. New York: Springer, 2012, s. 167199. https://doi.org/10.1007/978-1-4614-1287-8_11 
JOHNSON, S., KAUFMANN, D, MCMILLAN, J., and WOODRUFF, C. (2000). Why Do Firms Hide? Bribes and Unofficial Activity after Communism. Journal of Public Economics, 2000. Vol.76, No. 3, s. 495-520. https://doi.org/10.1016/S0047-2727(99)00094-8

KING, M.L., Jr. (1963). Letter from the Birmingham Jail. April 16. http://okra.stanford.edu/transcription/document images/undecided/630416-019.pdf

MCGEE, R. W. (2014). The Ethics of Tax Evasion: A Case Study of Brazil, in B. Christiansen (ed.), Handbook of Research on Economic Growth and Technological Change in Latin America, IGI Global, Hershey, PA, USA: IGI Global, 2014, s. 374-393. https://doi.org/10.4018/978-1-46666224-7.ch022

MCGEE, R. W. and SMITH, S.R. (2012). Ethics, Tax Evasion and Religion: A Survey of Opinion of Members of the Church of Jesus Christ of Latter-day Saints, in R. W. McGee (ed.), The Ethics of Tax Evasion: Perspectives in Theory and Practice. New York: Springer, 2012, s. 211-226. https://doi.org/10.1007/978-1-4614-1287-8_13

MCGEE, R. W. (ed.), (2012). The Ethics of Tax Evasion: Perspectives in Theory and Practice. New York: Springer, 2012. https://doi.org/10.1007/978-1-4614-1287-8

PENNOCK, R.T. (1998). Death and Taxes: On the Justice of Conscientious War Tax Resistance. Journal of Accounting, Ethics \& Public Policy, 1998. Vol. 1, No. 1, s. 58-76.

RISTOVSKA, M., MOJSOSKA-BLAZESKI, N. and NIKOLOV, M. (2013). An Alternative View of Tax Evasion. The Effect of Tax Morale on Paying Taxes in Macedonia and EU Countries. Serbian Journal of Management 2013. Vol. 8, No. 2, s. 169-183. https://doi.org/10.5937/sjm8-3776

ROTHBARD, M. N. (1963). America's Great Depression. Kansas City: Sheed and Ward, 1963, s. 224226 and 296-304.

SCHANSBERG, D.E. (1998). The Ethics of Tax Evasion within Biblical Christianity: Are there Limits to 'Rendering Unto Caesar?' Journal of Accounting, Ethics \& Public Policy 1998. Vol. 1, No. 1, s. 77-90.

SMITH, S.R. and KIMBALL, K.C. (1998). Tax Evasion and Ethics: A Perspective from Members of The Church of Jesus Christ of Latter-Day Saints. Journal of Accounting, Ethics \& Public Policy 1998. Vol. 1, No. 3, s. 337-348.

TAMARI, M. (1998). Ethical Issues in Tax Evasion: A Jewish Perspective. Journal of Accounting, Ethics \&. Public Policy 1998. Vol. 1, No. 2, s. 121-132.

TORGLER, B. (2011). Tax Morale and Compliance. The World Bank, Europe and Central Asia Region. Working Paper Series 5922.

TORGLER, B. (2007). Tax Compliance and Tax Morale: A Theoretical and Empirical Analysis, Cheltenham, UK: Edward Elgar, 2007. https://doi.org/10.4337/9781847207203

USLANER, E.M. (2008). Tax Evasion, Corruption, and the Social Contract in Transition. London: Routledge, 2008.

VEDDER, R.K. and GALLAWAY, L. (1991). The Great Depression of 1946. The Review of Austrian Economics 1991. Vol. 5, No. 2, s. 3-32. https://doi.org/10.1007/BF02426926

YUSUF, S. M. (1971). Economic Justice in Islam. Lahore, India: Sh. Muhammad Ashraf, 1971. 